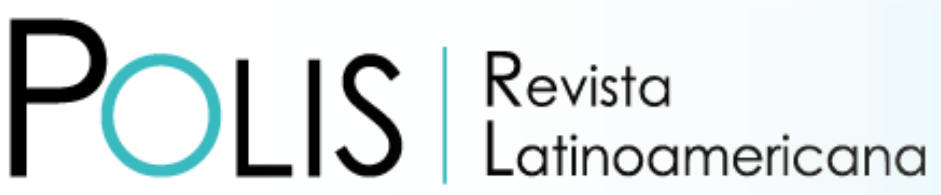

V20 | N59 | 2021

DOI:10.32735/S0718-6568/2021-N59-1502

\title{
Partidos políticos e o aborto: análise a partir dos pronunciamentos na Câmara dos Deputados do Brasil e do Uruguai (1985-2016)
}

\author{
Luis Gustavo Teixeira da Silva \\ Universidade Federal de Pelotas (UFPel), Pelotas, Brasil \\ Email: gustavoteixeira2519@gmail.com
}

Recibido:01.05.2020 | Aceptado: 07.01.2021

\begin{abstract}
Resumo: O objetivo deste artigo é analisar a relação entre a filiação partidária dos/as parlamentares e suas respectivas posições sobre o aborto. Para realizar a pesquisa utilizamos como metodologia a análise dos pronunciamentos dos/as parlamentares proferidos na Câmara dos Deputados do Brasil e do Uruguai, entre 1985-2016. O texto está dividido em três seções: na primeira apresentamos os elementos metodológicos adotados; nas demais seções examinamos a formação dos sistemas partidários de Brasil e Uruguai e analisamos o modo como as posições sobre o aborto foram expressas, conforme a filiação partidária.
\end{abstract}

Palavras-chave: Aborto; poder legislativo; partidos políticos; Brasil; Uruguai.

\section{Partidos políticos y el aborto: análisis a partir de los pronunciamientos en la Cámara de Diputados de Brasil y Uruguay (1985-2016)}

Resumen: El propósito de este artículo es analizar la relación entre la afiliación partidaria de los parlamentarios y sus respectivas posiciones con respecto al aborto. Para llevar a cabo esta investigación utilizamos como metodología el análisis de los pronunciamientos de los parlamentarios proferidos en la Cámara de Diputados de Brasil y de Uruguay, entre 1985-2016. El texto se divide en tres secciones: en la primera, presentamos los elementos metodológicos adoptados; en las otras secciones, examinamos la formación de los sistemas de partidos en Brasil y Uruguay y analizamos el modo como las posiciones sobre el aborto fueron expresas, según la afiliación partidaria.

Palabras-clave: Aborto; poder legislativo; partidos políticos; Brasil; Uruguay.

\section{Political Parties and Abortion: Analysis based on Pronouncements in the House of Representatives of Brazil and Uruguay (1985-2016)}

Abstract: The purpose of this article is to analyze the relationship between the party affiliation of parliamentarians and their respective positions regarding abortion. To carry out this re- 
search is based on an analysis of the pronouncements of the parliamentarians in the Chamber of Deputies of Brazil and of Uruguay, between 1985-2016. The text is divided into three sections: in the first, we present the methodological elements adopted; in the other sections, we examine the formation of the party systems in Brazil and Uruguay and analyze how the positions on abortion were expressed, according to party affiliation.

Keywords: Abortion; legislative power; political parties; Brazil; Uruguay.

\section{Como citar este artículo:}

Teixeira da Silva, L. (2021). Partidos políticos e o aborto: análise a partir dos pronunciamentos na Câmara dos Deputados do Brasil e do Uruguai (1985-2016). Polis Revista Latinoamericana, 20 (59), 246-271. doi: http://dx.doi.org/10.32735/S0718-6568/2021-N59-1502

\section{Introdução}

O objetivo do texto é analisar a relação entre a filiação partidária dos/as parlamentares e suas respectivas posições sobre o aborto. A proposta é apresentar um panorama geral dos resultados aferidos pela investigação, explorando os dados em sua formação integral, proporcional e distribuição na série histórica, com a realização de inferências sobre as evidências expostas. Duas perguntas de partida orientam a redação: 1) É possível identificar um padrão que permita relacionar a posição dos/as parlamentares de acordo com a inclinação ideológica do partido político que estão filiados? Essa questão possibilita discutir a hipótese, amparada em certo consenso no debate público e acadêmico, de que parlamentares vinculados a partidos políticos mais à esquerda são preponderantemente os/ as principais interlocutores na demanda pela descriminalização do aborto, enquanto parlamentares vinculados a partidos mais a direita seriam os/as protagonistas para impor obstáculos aos direitos reprodutivos das mulheres. A segunda pergunta consiste na verificação de um fenômeno em ascensão, com distintos graus, nos países da América Latina: 2) Qual a atuação de representantes políticos alinhados às igrejas cristãs, evangélica ou católica, e seu efeito na discussão em plenário sobre o aborto.

Para analisar esse cenário subdividimos o texto em três seções: na primeira apresentamos brevemente os elementos metodológicos adotados para a realização da pesquisa, assim; nas demaisseçõesexaminamosaformação dossistemaspartidários de BrasileUruguaie analisamos o modo como as posições sobre o aborto foram expressas, conforme a filiação partidária.

\section{Metodologia da pesquisa e contexto dos dados}

A metodologia da pesquisa se baseou na análise dos pronunciamentos sobre o aborto, proferidos pelos/as deputados/as que compõem a Câmara dos Deputados do Brasil e a Câmara de Representantes do Uruguai, entre os anos de 1985 e 2016, logo, todas as manifestações de fala realizadas em plenário desde o início do governo civil até os dias atuais. 
Essa pesquisa foi iniciada em 2012 ese concentrou nos dados do legislativo brasileiro, coletados e analisados no âmbito do Grupo de Pesquisa Democracia e Desigualdades, coordenado

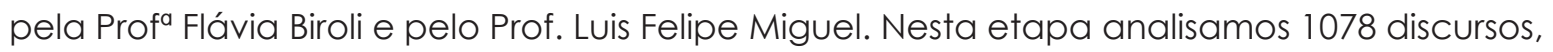
proferidos entre janeiro de 1985 e dezembro de 2016 , período que abrange a $47^{a}$ legislatura até a $55^{\circ}$ legislatura. A pesquisa na Câmara de Representantes do Uruguai foi efetuada a partir de 2014, após a conclusão parcial da realizada na Câmara dos Deputados do Brasil. Na Câmara de Representantes do Uruguai foram coletados e analisados 337 discursos, proferidos entre janeiro de 1985 e dezembro de 2016, entre a $42^{\circ}$ legislatura até a $48^{\circ}$ legislatura (Silva, 2018).

Para estabelecer uma análise comparativa foram adotados os mesmos procedimentos, salvo por pequenas adequações executadas, principalmente idiomáticas. Portanto, apesar das enormes diferenças entre Brasil e Uruguai (por exemplo, demográficas, territoriais e sociais), entendemos que a análise comparativa se sustentou neste caso pelo fato de nos concentrarmos nas falaselaboradas pelos/as representantes políticos/as de uma instituição do Estado circunscrita, que possuem função similar no regime democrático.

Nesta análise comparativa precisamos levar em consideração o contexto em que os discursos foram proferidos. Do ponto de vista institucional precisamos ressaltar alguns pontos. Em primeiro lugar, pontuar que no Brasil são eleitos/as 513 deputados/as federais, para o exercício do mandato em legislatura com duração de 4 anos. No Uruguai são eleitos 99 deputados/as à Câmara de Representantes, para legislatura com duração de 5 anos. Essa composição em parte explica a proporção dos discursos pronunciados em cada país. Por último, do ponto de vista legal, é necessário sinalizar que a legislação brasileira, desde 1940, criminaliza o aborto, com atenuante para gestações resultantes de estupro, quando há risco de vida da gestante e, em 2012, por ação do Poder Judiciário, em fetos diagnosticados com anencefalia. No Uruguai o aborto foi criminalizado em 1938, com atenuantes para casos de estupro, risco de saúde ou vida da gestante, penúria econômica e honra, esta legislação vigorou até o ano de 2012, quando o aborto foi descriminalizado.

Após o processo de seleção, todos os pronunciamentos foram lidos e analisados. Para cada discurso uma ficha no software estatístico Sphinx Lexica foi preenchida, com 32 variáveis de classificação dos discursos. A utilização deste instrumento foi de suma importância à sistematização das informações, realizado em três etapas. A primeira consistiu na documentação da fala parlamentar, na segunda etapa foram registradas as informações de identificação do/a parlamentar pronunciante, a última etapa consistiu em classificar o conteúdo expresso em cada discurso (em nota de pesquisa apresento a ficha completa e as formas de utilização das categorias, ver: Silva, 2017).

Neste texto analisaremos a relação entre a filiação partidária dos/as parlamentares e suas posições quanto ao aborto. Assim, salientamos que vamos explorar os resultados obtidos por variáveis específicas. A primeira delas é a intitulada:Partido, que serviu para assinalar qual o partido político que o/a orador/a estava filiado/a no momento do pronunciamento. A segunda variável é a Posiçãosobre a interrupção voluntária da gestação. Esta variável 
é composta por sete categorias, que abrangem os distintos posicionamentos sobre a matéria. Para cada fala era possível assinalar até duas categorias: $1^{\circ}$ a favor da ampliação do aborto legal; $2^{\circ}$ a favor da manutenção da lei; $3^{\circ}$ a favor da restrição do aborto legal; $4^{\circ}$ contra o aborto (genérico); $5^{\circ}$ por novas medidas punitivas e/ou de controle; $6^{\circ}$ pela educação sexual e/ou planejamento familiar; $7^{\circ}$ não se posiciona ${ }^{l}$.

Nos casos em que o discurso era a favor da ampliação do aborto legal, imediatamente o preenchimento da ficha remetia a identificação da Posição Específica, em cada caso era possível marcar até quatro alternativas: $1^{\circ}$ descriminalização total; $2^{\circ}$ permissão em caso de inviabilidade do feto; $3^{\circ}$ ampliação da assistência da rede hospitalar; $4^{\circ}$ não indica que tipo de ampliação; e/ou $5^{\circ}$ outra ampliação.

Mesmo procedimento ocorreu quando a posição do pronunciamento era: a favor da restrição do aborto legal e/ou por novas medidas punitivas e/ou de controle, em queera possível designar até cinco alternativas: $1^{\circ}$ proibição total; $2^{\circ}$ estupro; $3^{\circ}$ risco de vida da mãe; $4^{\circ}$ inviabilidade do feto; $5^{\circ}$ políticas de repressão ao aborto; e/ou $6^{\circ}$ outra restrição. As variáveis designadas a identificar a posição parlamentar, e suas respectivas categorias, exerceram papel significativo na catalogação adequada dos discursos. Por meio desse processo tornou-se possível apresentar e escalonar as gradações entre as distintas inclinações expressas nas falas.

\section{Partidos políticos e o aborto no Brasil}

O sistema partidário brasileiro é remanescente do processo de liberalização iniciado pela lei partidária de 1979, que extinguiu o bipartidarismo vigente desde 1966, tutelado pela ditadura militar (Kinzo 2001). A partir disso, novas e antigas legendas foram (re) criadas, entre estas: PDS, PMDB, PTB, PDT e PT. O Partido Democrático Social (PDS) foi sucessor e herdeiro político da Aliança Renovadora Nacional (ARENA), então partido de sustentação da ditadura militar. Por sua vez, o Partido do Movimento Democrático Brasileiro (PMDB) era herdeiro do MDB, partido de oposição à ditadura, embora chancelado pelo regime. O PMDB conservou seu peso político, com alto percentual de representação no legislativo desde sua criação. O Partido Trabalhista Brasileiro (PTB), de inclinação ideológica conservadora, surgiu de uma cisão com o MDB, sobretudo da fração menos oposicionista ao regime militar. Ao utilizar o mesmo nome e sigla, este partido buscou se associar a história do PTB de Getúlio Vargas (Motta 2008). Igualmente inspirado no Varguismo o Partido Democrático Trabalhista (PDT) foi liderado e conduzido por Leonel Brizola, uma das mais notáveis figuras do trabalhismo na política brasileira (Silva, 2018).

O Partido dos Trabalhadores (PT) foi criado a partir de uma conjunção de forças sociais e políticas, congregando movimentos sociais, a Igreja Católica, sindicatos, grupos marxistas,

1 Os dados dessa categoria não serão analisados, pelo fato de seus resultados não serem suficientes relevantes nesta abordagem, especialmente pela ausência de conteúdo. 
entre outras organizações. Por este motivo, segundo Motta (2008), este partido foi uma das construções mais originais da política nacional. Sustentado por um discurso crítico às relações de poder e as elites, o PT se transformou em um dos partidos com maior peso político do sistema partidário brasileiro a partir de sua fundação.

A Emenda Constitucional $n^{\circ} 25$ de 1985 inaugurou uma nova fase do sistema partidário brasileiro, pois eliminou as restrições para a criação de novos partidos, inclusive aqueles de orientação marxista que até então eram ilegais (Lamounier e Meneguello 1987; Kinzo 2001). Esta medida possibilitou a ampliação do sistema partidário, que já a época se converteria em um pluralismo atomizado, isto é, composto por uma miríade de partidos em competição pelo poder político, com isso dificultando a governabilidade e a formação de governos de coalizão.

De uma ruptura com o PMDB (MDB) surgem muitos partidos com inclinações ideológicas distintas. Á esquerda emergem o Partido Socialista Brasileiro (PSB) e o Partido Comunista do Brasil (PCdoB), ambos remanescentes históricos de partidos com mesmo nome e sigla, que se tornaram ilegais durante o regime militar, fundados em 1947 e 1922, respectivamente. O Partido Verde (PV) representou uma nova agremiação, composta por intelectuais de esquerda que se propunham a inserir na agenda política questões ambientais e climáticas. Os dois primeiros partidos conquistaram desde suas (re) fundações peso político baixo/mediano dependendo da legislatura, já o PV sempre foi uma força periférica. Mais ao centro do espectro partidário surgiu o Partido da Social Democracia Brasileira (PSDB), também fruto de uma cisão com o PMDB. Fundado em 1988, por grupos intelectuais de centro-esquerda, apesar disso pouco a pouco o partido se inclinou mais ao centro-direita. A partir de sua criação o PSDB se transformou em um dos principais partidos, com êxito razoável em todos os níveis de governo (Motta 2008; Rodrigues, 2002)².

A progressiva perda de influência do regime militar e do PDS, partido de situação, conduziu a ruptura e a fundação do Partido da Frente Liberal (PFL) em $1985^{3}$ e do Partido Progressista (PP/PPR/PPB) em 1993, situados à direita no espectro ideológico. Ambos sempre tiveram peso importante no legislativo brasileiro, embora nos últimos dez anos com parcial tendência a queda. Em 2011 foi criado o Partido Social Democrático (PSD), por dissidentes do PFL/ DEM e do PP/PPR/PPB. Em 1989 foi criado o Partido de Reedificação da Ordem Nacional (PRONA), partido de extrema-direita com força periférica no legislativo. Em 2007 o PRONA se fundiu com o Partido Liberal (PL), fundado em 1985, dessa fusão surgiu o Partido da República (PR). Contudo, em 2011 o PRONA foi novamente refundado.

Esse ponto permite abordar a formação dos partidos políticos de caráter confessional no Brasil. O Partido Liberal, refundado sob a sigla de Partido da República, possui uma vinculação com a Igreja Universal do Reino de Deus (IURD). As lideranças políticas e religiosas da IURD (como o Bispo Marcelo Crivella) fundaram também, em 2006, o Partido Republicano

2 Entre as muitas classificações ideológicas dos partidos brasileiros adotamos a formulada/operacionalizada por Leôncio Martins Rodrigues (2002) e Adriano Codato, Fábia Berlatto e Bruno Bolognesi (2018).

3 Em função do desgaste da sigla o PFL a partir de 2007 foi refundado com o nome Democratas (DEM). 
Brasileiro (PRB), igualmente de inclinação conservadora. Neste mesmo espectro ideológico, o Partido Social Cristão (PSC), fundado em 1985 e registrado em 1990, é desde sua criação, em parte, associado a grupos da igreja Assembleia de Deus (AD). Por sua vez, o Partido Humanista da Solidariedade (PHS), de 1995, foi fundado por grupos ligados ao catolicismo. Sua composição ideológica se caracteriza por posições de centro-direita, atualmente é preponderantemente composto por políticos associados à Renovação Carismática Católica. O PHS sempre representou uma força política com baixa representatividade, já os partidos vinculados às igrejas evangélicas possuem impacto mediano em termos de representação na Câmara dos Deputados (Codato; Berlatto; Bolognesi, 2018).

Este esboço pretendeu delinear quais são e em que circunstâncias surgiram aqueles partidos políticos com influência no sistema político e maior atuação em plenário sobre o aborto. Decerto que os partidos no Brasil são instituições complexas, com variações internas e regionais, no entanto aos nossos propósitos essa identificação contribui para fornecer alguns subsídios preliminares para compreender os dados. Abaixo apresentamos a tabela contendo o posicionamento dos partidos. 
Tabela 1:

Distribuição dos discursos com a posição dos partidos políticos no Brasil, em números absolutos e percentuais (em linha), entre 1985-20164.

\begin{tabular}{|c|c|c|c|c|c|c|c|c|c|c|c|c|c|c|}
\hline \multirow{2}{*}{$\begin{array}{l}\text { Posiçã } \\
\text { o- }\end{array}$} & \multicolumn{2}{|c|}{$\begin{array}{c}\text { A favor da } \\
\text { ampliação } \\
\text { do aborto } \\
\text { legal }\end{array}$} & \multicolumn{2}{|c|}{$\begin{array}{c}\text { A favor da } \\
\text { manutenç } \\
\text { āo da lei }\end{array}$} & \multicolumn{2}{|c|}{$\begin{array}{c}\text { A favor da } \\
\text { restrição } \\
\text { do aborto } \\
\text { legal }\end{array}$} & \multicolumn{2}{|c|}{$\begin{array}{c}\text { Contra o } \\
\text { aborto } \\
\text { (genérico) }\end{array}$} & \multicolumn{2}{|c|}{$\begin{array}{l}\text { Por novas } \\
\text { medidas } \\
\text { punitivas } \\
\text { e/ou de } \\
\text { controle }\end{array}$} & \multicolumn{2}{|c|}{$\begin{array}{c}\text { Pela } \\
\text { educação } \\
\text { sexual e/ou } \\
\text { planejamen } \\
\text { to familiar }\end{array}$} & \multicolumn{2}{|c|}{ Total } \\
\hline & $\mathbf{Q}$ & $\%$ & Q & $\%$ & $Q$ & $\%$ & $Q$ & $\%$ & $Q$ & $\%$ & $\mathbf{Q}$ & $\%$ & Q & $\%$ \\
\hline PDS & 1 & $5 \%$ & 3 & $16 \%$ & 0 & $0 \%$ & 13 & $69 \%$ & 1 & $5 \%$ & 1 & $5 \%$ & 19 & $100 \%$ \\
\hline $\begin{array}{l}\text { PFL/ } \\
\text { DEM }\end{array}$ & 15 & $11 \%$ & 25 & $18 \%$ & 34 & $25 \%$ & 43 & $31 \%$ & 7 & $5 \%$ & 13 & $10 \%$ & 137 & $100 \%$ \\
\hline $\begin{array}{c}\text { PP/PPB/ } \\
\text { PPR }\end{array}$ & 3 & $3 \%$ & 19 & $17 \%$ & 24 & $22 \%$ & 33 & $30 \%$ & 17 & $15 \%$ & 14 & $13 \%$ & 110 & $100 \%$ \\
\hline PL/PR & 1 & $2 \%$ & 10 & $24 \%$ & 5 & $12 \%$ & 14 & $33 \%$ & 8 & $19 \%$ & 4 & $10 \%$ & 42 & $100 \%$ \\
\hline PRONA & 0 & $0 \%$ & 6 & $22 \%$ & 5 & $18 \%$ & 11 & $41 \%$ & 4 & $15 \%$ & 1 & $4 \%$ & 27 & $100 \%$ \\
\hline PSD & 1 & $5 \%$ & 3 & $16 \%$ & 1 & $5 \%$ & 8 & $4 Z \%$ & 3 & $16 \%$ & 3 & $16 \%$ & 19 & $100 \%$ \\
\hline PIB & 6 & $7 \%$ & 12 & $15 \%$ & 14 & $17 \%$ & 26 & $32 \%$ & 14 & $17 \%$ & 10 & $12 \%$ & 83 & $100 \%$ \\
\hline PSC & 0 & 0 & 8 & $16 \%$ & 10 & $20 \%$ & 24 & $46 \%$ & 4 & $8 \%$ & 5 & $10 \%$ & 51 & $100 \%$ \\
\hline PRB & 0 & $0 \%$ & 6 & $24 \%$ & 1 & $4 \%$ & 15 & $64 \%$ & 2 & $8 \%$ & 0 & 0 & 23 & $100 \%$ \\
\hline PHS & 0 & $0 \%$ & 4 & $13 \%$ & 3 & $10 \%$ & 13 & $42 \%$ & 11 & $35 \%$ & 0 & $0 \%$ & 31 & $100 \%$ \\
\hline PMDB & 12 & $10 \%$ & 16 & $13 \%$ & 17 & $14 \%$ & 57 & $47 \%$ & 11 & $9 \%$ & 9 & $7 \%$ & 122 & $100 \%$ \\
\hline PSDB & 3 & $3 \%$ & 19 & $22 \%$ & 22 & $25 \%$ & 30 & $33 \%$ & 12 & $13 \%$ & 4 & $4 \%$ & 89 & $100 \%$ \\
\hline PT & 86 & $37 \%$ & 25 & $11 \%$ & 11 & $4 \%$ & $\angle B$ & $29 \%$ & 17 & $7 \%$ & 28 & $12 \%$ & 235 & $100 \%$ \\
\hline PCdoB & 23 & $64 \%$ & 7 & $18 \%$ & 0 & $0 \%$ & 0 & $0 \%$ & 0 & $0 \%$ & 7 & $18 \%$ & 37 & $100 \%$ \\
\hline POI & 6 & $17 \%$ & 9 & $25 \%$ & 4 & $12 \%$ & 6 & $17 \%$ & 3 & $9 \%$ & 7 & $20 \%$ & 35 & $100 \%$ \\
\hline PPS & 2 & $16 \%$ & 0 & O\% & 2 & $16 \%$ & 3 & $28 \%$ & 1 & $8 \%$ & 4 & $32 \%$ & 12 & $100 \%$ \\
\hline PSB & 5 & $\%$ & 14 & $23 \%$ & 3 & $5 \%$ & 23 & $37 \%$ & 7 & $11 \%$ & 10 & $16 \%$ & 62 & $100 \%$ \\
\hline PSOL & 8 & $80 \%$ & 2 & $20 \%$ & 0 & $0 \%$ & 0 & $0 \%$ & 0 & $0 \%$ & 0 & $0 \%$ & 10 & $100 \%$ \\
\hline PV & 2 & $4 \%$ & 10 & $18 \%$ & 7 & $13 \%$ & 20 & $36 \%$ & 12 & $21 \%$ & 4 & $8 \%$ & 55 & $100 \%$ \\
\hline Total & 174 & $14,5 \%$ & 198 & $16,5 \%$ & 163 & $13,6 \%$ & 407 & $34 \%$ & 133 & $11,1 \%$ & 124 & $10,3 \%$ & 1199 & $100 \%$ \\
\hline
\end{tabular}

Fonte: Elaboração própria. Obs.: Era possível marcar até duas posições em cada discurso.

Os/as parlamentares dos partidos políticos situados à direita e centro-direita (são eles: PFL/ DEM, PP/PPB/PPR, PTB, PSC, PRB, PRONA, PL/PR, PSD, PDS e PHS), sustentaram o maior número de posições contrárias ao aborto. De forma agregada, os/as deputados/as vinculados aos partidos supracitados proferiram 460 discursos sobre o tema $(42,7 \%$ do total de 1078 
discursos), destes, em 200 discursos a posição contra o aborto - genérico foi sustentada (equivalente a 43,5\% de 460 discursos), 97 (21\% de 460) falas a favor da restrição do aborto legal e 71 (15,5\%) por novas medidas punitivas e/ou de controle.

Nas duas últimas categorias era possível designar o tipo de restrição a que os pronunciamentos faziam menção, neste caso, entre os/as parlamentares dos partidos à direita e centro-direita, foi identificado que 61 (13\% de 460) discursos defenderam a proibição total do aborto, 23 (5\%) nos casos de estupro, em dois discursos nos casos de risco de vida da gestante, em seis $(1,3 \%)$ nas situações de inviabilidade do feto e 23 (5\%) sustentaram a necessidade de políticas de repressão ao aborto. Abaixo apresentamos a tabela com os dados desagregados.

\section{Tabela 2:}

Distribuição dos discursos de acordo com o tipo de restrição ao aborto nos partidos à direita e centro-direita no Brasil, em números absolutos e percentuais (em linha), entre 1985 e 2016.

\begin{tabular}{|c|c|c|c|c|c|c|c|c|c|c|c|c|}
\hline $\begin{array}{c}\text { Restrição- } \\
\text { Partido } \downarrow\end{array}$ & $\begin{array}{c}\text { Proibiçāo } \\
\text { total }\end{array}$ & \multicolumn{2}{|c|}{ Estupro } & \multicolumn{2}{|c|}{$\begin{array}{c}\text { Risco de } \\
\text { vida }\end{array}$} & $\begin{array}{c}\text { Inviabili- } \\
\text { dade do } \\
\text { feto }\end{array}$ & $\begin{array}{c}\text { Políticas de } \\
\text { repressão ao } \\
\text { aborto }\end{array}$ & \multicolumn{2}{|c|}{ Total } \\
\hline PFL/DEM & 22 & $63 \%$ & 9 & $26 \%$ & 0 & $0 \%$ & 1 & $3 \%$ & 3 & $8 \%$ & 35 & $100 \%$ \\
\hline PL/PR & 4 & $58 \%$ & 0 & $0 \%$ & 0 & $0 \%$ & 0 & $0 \%$ & 3 & $42 \%$ & 7 & $100 \%$ \\
\hline PP/PPB/PPR & 18 & $62 \%$ & 7 & $24 \%$ & 2 & $7 \%$ & 0 & $0 \%$ & 2 & $7 \%$ & 29 & $100 \%$ \\
\hline PRONA & 5 & $72 \%$ & 0 & $0 \%$ & 0 & $0 \%$ & 0 & $0 \%$ & 2 & $28 \%$ & 7 & $100 \%$ \\
\hline PSC & 1 & $9 \%$ & 5 & $41 \%$ & 0 & $0 \%$ & 2 & $17 \%$ & 4 & $33 \%$ & 12 & $100 \%$ \\
\hline PTB & 11 & $61 \%$ & 1 & $5 \%$ & 0 & $0 \%$ & 0 & $0 \%$ & 6 & $34 \%$ & 18 & $100 \%$ \\
\hline PRB & 0 & $0 \%$ & 1 & $25 \%$ & 0 & $0 \%$ & 1 & $25 \%$ & 2 & $50 \%$ & 4 & $100 \%$ \\
\hline PSD & 0 & $0 \%$ & 0 & $0 \%$ & 0 & $0 \%$ & 2 & $75 \%$ & 1 & $25 \%$ & 3 & $100 \%$ \\
\hline Total & 61 & $53 \%$ & 23 & $20 \%$ & 2 & $1,5 \%$ & 6 & $5,5 \%$ & 23 & $20 \%$ & 115 & $100 \%$ \\
\hline
\end{tabular}

Fonte: Elaboração própria. Obs: Era possível marcar até cinco alternativas.

É preciso ponderar que a maior parte destes partidos defende em seus programas a construção/preservação de uma agenda moral conservadora para o Brasil, assim como a rejeição a ampliação do direito ao aborto. Igualmente, considerar que boa parte dos/as parlamentares ligados as clivagens religiosas (evangélicas e católicas) atuam no interior destas legendas. Portanto, a conjunção destes fatores ajuda a explicar a mobilização contrária dos/as parlamentares destas legendas para conter medidas que consideram incompatíveis com os valores morais e/ou convicções religiosas defendidas por este segmento. Por exemplo, é possível notar na tabela 1 que a ampla maioria dos pronunciamentos dos/ as parlamentares filiados aos partidos de caráter confessional, como PSC, PL/PR, PRB e PHS, se concentram no espectro de tácita oposição ao aborto.

A posição a favor da ampliação do aborto legal foi identificada em 27 falas (6\% de 460), sobretudo proferidas pelos/as deputados/as do PFL/DEM (15) e PTB (6), principalmente: Nobel Moura (PTB), Ciro Nogueira (PFL/DEM), Inocência Oliveira (PFL/DEM), Roland Lavigne (PFL/DEM), Betinho Rosado (PFL/DEM), Luiz Antonio Fleury (PTB), João Batista (PFL/DEM), Dr. Pinoti (PFL/DEM), Sandes Junior (PFL/DEM), Dirce Tutu Quadros (PTB). O tipo de ampliação 
assinalado nestes pronunciamentos corresponde a seguinte distribuição: oito (1,8\% de 460$)$ discursos se posicionaram pela descriminalização total; 10 (2,2\%) pela permissão em casos de inviabilidade do feto e 15 (3,3\%) pela ampliação da assistência na rede pública. Na tabela abaixo apresentamos os dados desagregados, por partido político.

Tabela 3:

Distribuição dos discursos de acordo com o tipo de ampliação de acesso ao aborto nospartidos à direita e centro-direita no Brasil, em números absolutos e percentuais (em linha), entre 1985 e 2016.

\begin{tabular}{|c|c|c|c|c|c|c|c|c|c|c|c|c|}
\hline \multirow{2}{*}{$\begin{array}{c}\text { Ampliação } \rightarrow \\
\text { Partidos } \downarrow \\
\text { PFL/DEM }\end{array}$} & \multicolumn{2}{|c|}{$\begin{array}{c}\text { Descrimin } \\
\text { a-lização } \\
\text { total }\end{array}$} & \multicolumn{2}{|c|}{$\begin{array}{l}\text { Em caso } \\
\text { de } \\
\text { inviabilida } \\
\text { de do feto }\end{array}$} & \multicolumn{2}{|c|}{$\begin{array}{c}\text { Ampliação } \\
\text { assistência } \\
\text { na rede } \\
\text { hospitalar }\end{array}$} & \multicolumn{2}{|c|}{$\begin{array}{c}\text { Não } \\
\text { indica que } \\
\text { tipo de } \\
\text { ampliaçã } \\
0\end{array}$} & \multicolumn{2}{|c|}{ Outro } & \multicolumn{2}{|c|}{ Total } \\
\hline & 3 & $15 \%$ & 8 & $40 \%$ & 9 & $45 \%$ & 0 & $0 \%$ & 0 & $0 \%$ & 20 & $100 \%$ \\
\hline $\mathrm{PL} / \mathrm{PR}$ & 0 & $0 \%$ & 1 & $100 \%$ & 0 & $0 \%$ & 0 & $0 \%$ & 0 & $0 \%$ & 1 & $100 \%$ \\
\hline PP/PPB/PPR & 1 & $33 \%$ & 0 & $0 \%$ & 2 & $67 \%$ & 0 & $0 \%$ & 0 & $0 \%$ & 3 & $100 \%$ \\
\hline PTB & 4 & $58 \%$ & 0 & $0 \%$ & 2 & $28 \%$ & 0 & $0 \%$ & 1 & $14 \%$ & 7 & $100 \%$ \\
\hline PSD & 0 & $0 \%$ & 0 & $0 \%$ & 1 & $100 \%$ & 0 & $0 \%$ & 0 & $0 \%$ & 1 & $100 \%$ \\
\hline PTB & 0 & $0 \%$ & 1 & $50 \%$ & 1 & $50 \%$ & 0 & $0 \%$ & 0 & $0 \%$ & 2 & $100 \%$ \\
\hline Total & 8 & $24 \%$ & 10 & $30 \%$ & 15 & $44 \%$ & 0 & $0 \%$ & 1 & $2 \%$ & 34 & $100 \%$ \\
\hline
\end{tabular}

Fonte: Elaboração própria. Obs: Era possível marcar até cinco alternativas. Por não haver discursos foram exclú́dos: PDS, PHS, PRONA, PSC, PRB

Os discursos a favor da ampliação do aborto legal podem ser avaliados como expressivos. Por exemplo, em comparação ao Partido Nacional do Uruguai, também de inclinação ideológica à direita, não foi possível registrar nenhum pronunciamento com este conteúdo, padrão identificado também nos partidos de caráter confessional no Brasil, como PSC, PRB e PHS. Como amostra disso destacamos o pronunciamento do Deputado Nobel Moura (PTB-RO), sobre as bases de seu Projeto de Lei 1097/91 para descriminalizar o aborto:

Todo dia é dia de discutir o aborto, pois todo dia muitas mulheres, centenas, morrem no Brasil, vítimas do abortamento feito no escuro, na ilegalidade. São mulheres jovens que o País perde por acreditar que o aborto seja crime. São mães, são trabalhadoras que o Brasil perde por acreditar que o aborto é um pecado. Srs. Deputados, pensando em modernizar o País, em dar opção de acesso à tecnologia médica à mulher é que propus, na semana passada, projeto de lei que visa à legalização do aborto. Propus que o aborto deva ser feito até a idade gestacional de dez semanas, por entender ser esse o limite ideal para a aplicação das melhores técnicas médicas e acreditar serem dez semanas tempo suficiente para a mulher tomar conhecimento da gravidez e decidir se ela é desejada. (Diários da Câmara dos Deputados, 28/05/91, p. 7790-91).

Mais do que isso, podemos estabelecer paralelos entre as outras legendas do Brasil. Neste cenário, excluindo o PT e PC do B, vamos notar que o número de posições favoráveis proferidas por estes partidos à direita e centro-direita é superior ao de todos os demais partidos de esquerda (PDT, PSOL, PPS, PSB e PV), que somados proferiram 23 discursos a favor da ampliação do aborto legal. Apesar da superioridade no número de representantes dos 
partidos políticos à direita e centro-direita na Câmara dos Deputados durante as legislaturas analisadas em relação aos partidos à esquerda, desde já este quadro instiga interrogações quanto à complexidade do fenômeno no legislativo brasileiro.

No gráfico abaixo apresentamos a distribuição na série histórica entre os discursos contrários ao aborto (três categorias fundidas ${ }^{5}$ ) e a favor da ampliação do aborto legal, entre os três principais partidos à direita e centro-direita no Brasil.

\section{Gráfico 1:}

Distribuição dos discursos contrários ao aborto (três categorias fundidas) e a favor da ampliação do aborto legal do PFL/DEM, PP/PPB/PPR e PTB, entre 1985-2016

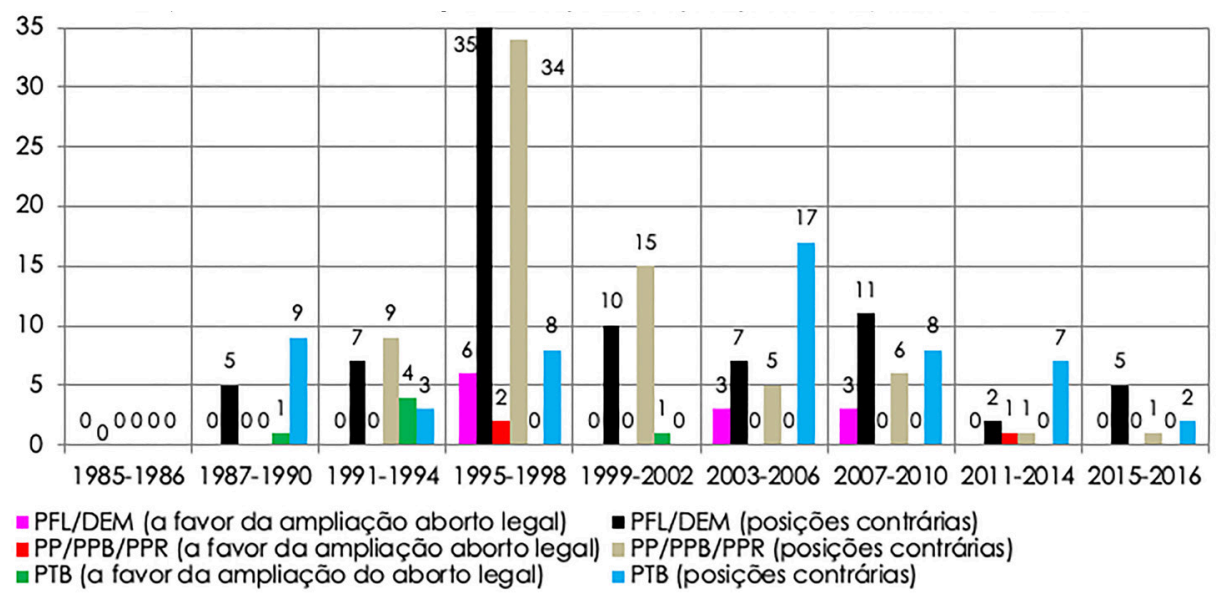

Fonte: Elaboração própria.

As mobilizações de fala dos/as parlamentares à direita e centro-direita contrários ao aborto apresentam elevação em contextos específicos, entre os principais estão: a defesa pela inclusão do direito à vida desde a concepção através da PEC 25/95 entre 1995-1998, e o Estatuto do Nascituro entre 2005 e 2010, cujo conteúdo similar a PEC25/95 inviabiliza o direito ao aborto nos casos já previstos em lei. Por outro lado são identificadas reações contrárias a iniciativas para ampliar o direito ao aborto, tais como: sua descriminalização em fetos diagnosticados com anencefalia, discutido e tramitado no Supremo Tribunal Federal, entre 2004 e 2012; e as Normas Técnicas do Ministério da Saúde, de 1999 e 2005, de iniciativa do Poder Executivo, para regulamentar o aborto nos casos já previstos na lei. As posições a favor da ampliação do aborto legal proferidas pelos/as parlamentares destes partidos estão dispersas entre diferentes legislaturas, não obstante podem ser avaliadas como vozes relevantes no interior destas estruturas partidárias nos contextos supracitados.

Os dois partidos mais ao centro no sistema político brasileiro, PMDB e PSDB, apresentam padrão semelhante no tocante às posições expressas pelas legendas à direita e centro-direita. De modo agregado, os 195 discursos (18,1\% de 1078) proferidos pelos/as parlamen-

5 Para melhor apresentar os dados, nos gráficos com as posições distribuídas na série histórica fundimos os resultados das categorias: Contra o aborto (genérico); a favor da restrição do aborto legal; por novas medidas punitivas elou de controle. 
tares do PMDB e PSDB (116 e 79, respectivamente) a posição contra o aborto (genérico) foi assumida em 87 pronunciamentos (45\% de 195 discursos), a favor da restrição do aborto legal em 39 (20\% de 195), já a posição por novas medidas punitivas e/ou de controle em 22 discursos (11,5\%).

Nas duas últimas categorias era possível designar o tipo de restrição, neste caso, 24 (12,3\% de 195) discursos assinalaram pela proibição total, 12 (6,2\%) nos casos de estupro, um (0,5\%) quando há risco de vida à gestante, dois (1\%) em casos de inviabilidade do feto e $10(5,1 \%)$ por políticas de repressão ao aborto. A posição a favor da ampliação do aborto legal foi manifestada em 15 falas $(7,8 \%)$, com a diferença de que 12 discursos foram proferidos pelos/as parlamentares do PMDB e apenas três pelos/as do PSDB. Nas tabelas abaixo apresentamos os dados desagregados.

\section{Tabela 4:}

Distribuição dos discursos de acordo com o tipo de restrição ao aborto nos partidos de centro no Brasil, em números absolutos e percentuais (em linha), entre 1985 e 2016.

\begin{tabular}{|c|c|c|c|c|c|c|c|c|c|c|c|c|}
\hline Restrição- & \multicolumn{2}{|c|}{$\begin{array}{c}\text { Proibição } \\
\text { total }\end{array}$} & \multicolumn{2}{|c|}{ Estupro } & $\begin{array}{c}\text { Risco de } \\
\text { vida da } \\
\text { mãe }\end{array}$ & $\begin{array}{c}\text { Inviabili- } \\
\text { dade do } \\
\text { feto }\end{array}$ & $\begin{array}{c}\text { Políticas de } \\
\text { repressão } \\
\text { ao aborto }\end{array}$ & \multicolumn{2}{|c|}{ Total } \\
\hline PSDB & 12 & $44 \%$ & 7 & $26 \%$ & 1 & $3,5 \%$ & 2 & $7,5 \%$ & 5 & $19 \%$ & 27 & $100 \%$ \\
\hline PMDB & 12 & $54 \%$ & 5 & $23 \%$ & 0 & $0 \%$ & 0 & $0 \%$ & 5 & $23 \%$ & 22 & $100 \%$ \\
\hline Total & 24 & $49 \%$ & 12 & $24 \%$ & 1 & $2 \%$ & 2 & $4 \%$ & 10 & $21 \%$ & 49 & $100 \%$ \\
\hline
\end{tabular}

Fonte: Elaboração própria. Obs: Era possível marcar até cinco alternativas.

Tabela 5:

Distribuição dos discursos de acordo com o tipo de ampliação de acesso ao aborto nos partidos de centro no Brasil, em números absolutos e percentuais (em linha), entre 1985 e 2016.

\begin{tabular}{|c|c|c|c|c|c|c|c|c|c|c|c|c|}
\hline \multirow{2}{*}{$\begin{array}{c}\text { Ampliaçāo } \rightarrow \\
\text { Partidos } \downarrow \\
\text { PMDB } \\
\end{array}$} & \multicolumn{2}{|c|}{$\begin{array}{c}\text { Descrimi- } \\
\text { nalizaçã } \\
\text { o total }\end{array}$} & \multicolumn{2}{|c|}{$\begin{array}{c}\text { Em caso } \\
\text { de } \\
\text { inviabilida } \\
\text { de do } \\
\text { feto }\end{array}$} & \multicolumn{2}{|c|}{$\begin{array}{c}\text { Ampliação } \\
\text { assistência } \\
\text { na rede } \\
\text { hospitalar }\end{array}$} & \multicolumn{2}{|c|}{$\begin{array}{l}\text { Não indica } \\
\text { que tipo } \\
\text { de } \\
\text { ampliação }\end{array}$} & \multicolumn{2}{|c|}{ Outro } & \multicolumn{2}{|c|}{ Total } \\
\hline & 4 & $29 \%$ & 3 & $22 \%$ & 6 & $43 \%$ & 0 & $0 \%$ & 1 & $6 \%$ & 14 & $100 \%$ \\
\hline PSDB & 3 & $60 \%$ & 0 & $0 \%$ & 2 & $40 \%$ & 0 & $0 \%$ & 0 & $0 \%$ & 5 & $100 \%$ \\
\hline Total & 7 & $37 \%$ & 3 & $16 \%$ & 8 & $42 \%$ & 0 & $0 \%$ & 1 & $5 \%$ & 19 & $100 \%$ \\
\hline
\end{tabular}

Fonte: Elaboração própria. Obs: Era possível marcar até quatro alternativas.

A constatação inicial a se mensurar é que estes partidos obtiveram as maiores bancadas parlamentares durante o período de análise dos dados, inclusive o PMDB foi base de sustentação no legislativo de quase todos os governos pós-democratização, já o PSDB elegeu o Presidente Fernando Henrique Cardoso para dois mandatos (1995-2002). A partir disso, 
chama atenção o baixíssimo número de pronunciamentos a favor da ampliação do aborto legal no PMDB e PSDB, os quais estão concentrados majoritariamente entre 1987 e 1998 (ver abaixo:gráfico 2), levando em consideração que estes partidos são compostos por alas mais progressistas, principalmente por grupos em determinadas regiões do País.

Os pronunciamentos no espectro de oposição ao aborto podem ser avaliados como reflexo de parte da formação destes partidos, especialmente na região sul e sudeste do Brasil, os quais também são compostos por muitos representantes políticos vinculados às Frentes Parlamentares confessionais, como a evangélica e a católica, assim como às Frentes em apoio à vida. Por exemplo, as lideranças destes partidos na Câmara até 2016 eram os principais coordenadores das Frentes Parlamentares confessionais: Eduardo Cunha (PMDB-RJ) e João Campos (PSDB-GO), vinculados a Assembleia de Deus, e Osmânio Pereira (PSDB-MG), ligado a Renovação Carismática Católica.

\section{Gráfico 2:}

\section{Distribuição dos discursos contrários ao aborto (três categorias fundidas) e a favor da ampliação do aborto legal do PMDB e do PSDB, entre 1985-2016}

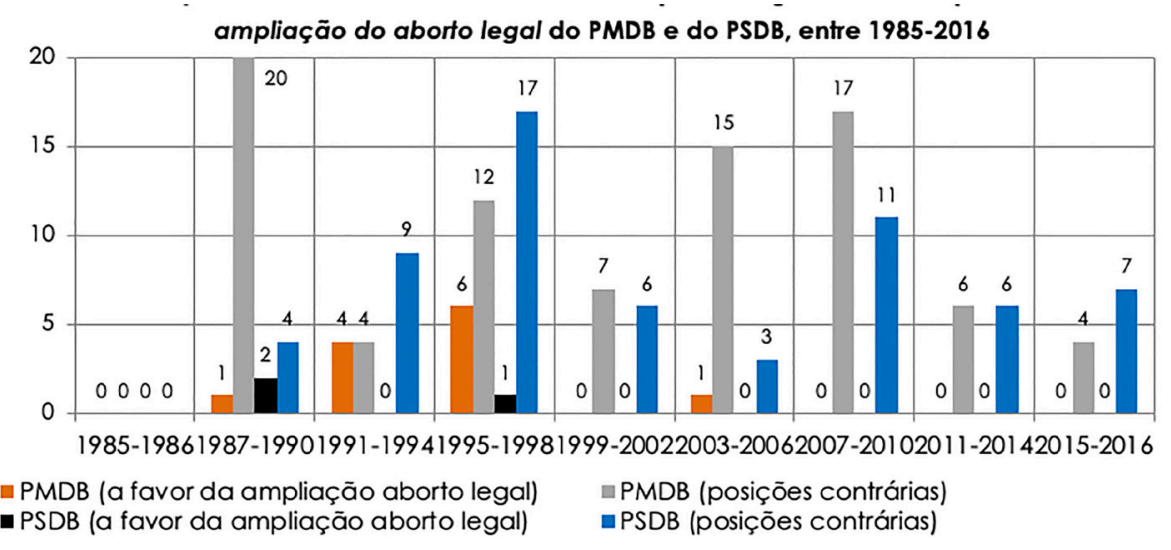

Fonte: Elaboração própria.

Conforme apontado anteriormente, os pronunciamentos a favor da ampliação do aborto legal são poucos e estão concentrados majoritariamente entre 1987 e 1998. Por sua vez os discursos contrários estão distribuídos na série histórica com elevação de acordo com as reações para impedir a ampliação do no direito ao aborto, em contextos similares a mobilização em plenário dos/as parlamentares à direita e centro-direita, ou seja, a PEC 25/95 (entre 1995 e 1998), Estatuto do Nascituro (2005 e 2010), aborto por anencefalia (2004 e 2012) e as Normas Técnicas do Ministério da Saúde (1999 e 2005). Contudo, entre os partidos ao centro, sobretudo no PMDB, há uma atuação significativa durante a deliberação da Constituição de 1988, não identificada nos demais partidos.

As posições pela educação sexual e/ou planejamento familiare a favor da manutenção da lei são difusas, isto dito pois elas foram mobilizadas em diferentes contextos com conotações 
distintas, ou seja, tanto para expressar oposição ao aborto, como para defender a inclusão de programas e/ou impedir retrocessos na legislação. Neste caso vamos tratar em conjunto os partidos à direita, centro-direita (PFL/DEM, PP/PPB/PPR, PTB, PSC, PRB, PRONA, PL/PR, PSD, PDS e PHS) e os partidos de centro (PMDB e PSDB), devido à identificação de um padrão na mobilização destas posições. A posição pela educação sexual e/ou planejamento familiarfoi mobilizada principalmente para referendar manifestações contrárias, ou seja, eram defendidas políticas públicas para educação sexual e planejamento familiar de jovens e adultos enquanto alternativa a ampliação da legislação. Por seu turno, com relação à posição a favor da manutenção da lei há uma constatação similar, embora com aspecto peculiar. Neste sentido, a defesa da manutenção da lei foi defendida nas situações em que a discussão sobre possíveis alterações estavam sendo construídas/apresentadas em outras instâncias, tais como: o aborto por anencefalia no Poder Judiciário e as Normas Técnicas pelo PoderExecutivo. Portanto, essa posição em períodos específicos reflete o apelo à preservação da criminalização, sob a tramitação em outras esferas de temas relacionados ao assunto.

Os partidos políticos situados no campo à esquerda e centro-esquerda (como: PT, PC do B, PDT, PPS, PSB, PSOL e PV), proferiram 438 discursos (40,7\% de 1078). De modo agregado, 136 pronunciamentos (31\% de 438) se colocaram contra o aborto - genérico, 31 (7,1\%) a favor da restrição do aborto legal e 51 (11,7\%) discursos por novas medidas punitivas e/ou de controle. O tipo de restrição se distribuiu da seguinte forma: 15 (3,5\% de 438) discursos defenderam a proibição total, cinco $(1,2 \%)$ nos casos de estupro, oito $(1,8 \%)$ em situações de inviabilidade do feto e $36(8,2 \%)$ por políticas de repressão ao aborto. Na tabela abaixo apresentamos os dados desagregados.

Tabela 6:

Distribuição dos discursos de acordo com o tipo de restrição ao aborto nos partidos à esquerda e centro-esquerda no Brasil, em números absolutos e percentuais (em linha), entre 1985 e 2016.

\begin{tabular}{|c|c|c|c|c|c|c|c|c|c|c|c|c|}
\hline Restrição $\rightarrow$ & \multicolumn{2}{|c|}{$\begin{array}{l}\text { Proibição } \\
\text { total }\end{array}$} & \multicolumn{2}{|c|}{ Estupro } & \multicolumn{2}{|c|}{$\begin{array}{c}\text { Risco de } \\
\text { vida da } \\
\text { mañe }\end{array}$} & \multicolumn{2}{|c|}{$\begin{array}{c}\text { Inviabili- } \\
\text { dade do } \\
\text { feto }\end{array}$} & $\begin{array}{c}\text { Políticas } \\
\text { de } \\
\text { repressão } \\
\text { ao aborto }\end{array}$ & \multicolumn{3}{|c|}{ Total } \\
\hline PDT & 1 & $20 \%$ & 1 & $20 \%$ & 0 & $0 \%$ & 1 & $20 \%$ & 2 & $40 \%$ & 5 & $100 \%$ \\
\hline PHS & 3 & $23 \%$ & 0 & $0 \%$ & 0 & $0 \%$ & 0 & $0 \%$ & 10 & $77 \%$ & 13 & $100 \%$ \\
\hline PPS & 2 & $100 \%$ & 0 & $0 \%$ & 0 & $0 \%$ & 0 & $0 \%$ & 0 & $0 \%$ & 2 & $100 \%$ \\
\hline PSB & 2 & $28 \%$ & 0 & $0 \%$ & 0 & $0 \%$ & 1 & $14 \%$ & 4 & $58 \%$ & 7 & $100 \%$ \\
\hline PT & 7 & $32 \%$ & 4 & $18 \%$ & 0 & $0 \%$ & 0 & $0 \%$ & 11 & $50 \%$ & 22 & $100 \%$ \\
\hline PV & 0 & $0 \%$ & 0 & $0 \%$ & 0 & $0 \%$ & 6 & $40 \%$ & 9 & $60 \%$ & 15 & $100 \%$ \\
\hline Total & 15 & $24 \%$ & 5 & $9 \%$ & 0 & $0 \%$ & 8 & $13 \%$ & 36 & $54 \%$ & 64 & $100 \%$ \\
\hline
\end{tabular}

Fonte: Elaboração própria. Obs: Era possível marcar até cinco alternativas. Por não haver discursos foram excluídos: PSOL, PCdoB.

A posição a favor da ampliação do aborto legal foi identificada em 132 falas $(30,2 \%$ de 438 discursos), destes, 59 (13,5\%) pronunciamentos defenderam a descriminalização total; já em 15 (3,5\%) a permissão em casos de inviabilidade do feto e em 44 (10\%) a ampliação 
da assistência na rede pública. É importante ressaltar, conforme pode ser verificado nas tabelas, que este índice de posições aferidas entre os partidos à esquerda representa a ampla maioria dos pronunciamentos neste espectro da discussão, ou seja, por ampliações no direito ao aborto. Abaixo os dados desagregados.

Tabela 7:

Distribuição dos discursos de acordo com o tipo de ampliação de acesso ao aborto nos partidos à esquerda e centro-esquerda no Brasil, em números absolutos e percentuais (em linha), entre 1985 e 2016.

\begin{tabular}{|c|c|c|c|c|c|c|c|c|c|c|c|c|}
\hline \multirow{2}{*}{$\begin{array}{c}\text { Ampliação } \rightarrow \\
\text { Partidos } ! \\
\text { PCdoB } \\
\end{array}$} & \multicolumn{2}{|c|}{$\begin{array}{c}\text { Descrimi- } \\
\text { nalizaçã } \\
\text { o total }\end{array}$} & \multicolumn{2}{|c|}{$\begin{array}{c}\text { Em caso } \\
\text { de } \\
\text { inviabilida } \\
\text { de do feto }\end{array}$} & \multicolumn{2}{|c|}{$\begin{array}{c}\text { Ampliação } \\
\text { assistência } \\
\text { na rede } \\
\text { hospitalar }\end{array}$} & \multicolumn{2}{|c|}{$\begin{array}{c}\text { Não } \\
\text { indica que } \\
\text { tipo de } \\
\text { ampliaçã } \\
0\end{array}$} & \multicolumn{2}{|c|}{ Outro } & \multicolumn{2}{|c|}{ Total } \\
\hline & 8 & $31 \%$ & 5 & $19 \%$ & 8 & $31 \%$ & 5 & $19 \%$ & 0 & $0 \%$ & 26 & $100 \%$ \\
\hline PDT & 3 & $44 \%$ & 0 & $0 \%$ & 2 & $28 \%$ & 2 & $28 \%$ & 0 & $0 \%$ & 7 & $100 \%$ \\
\hline PPS & 1 & $50 \%$ & 0 & $0 \%$ & 1 & $50 \%$ & 0 & $0 \%$ & 0 & $0 \%$ & 2 & $100 \%$ \\
\hline PSB & 4 & $66 \%$ & 0 & $0 \%$ & 1 & $17 \%$ & 1 & $17 \%$ & 0 & $0 \%$ & 6 & $100 \%$ \\
\hline PSOL & 3 & $30 \%$ & 1 & $10 \%$ & 3 & $30 \%$ & 2 & $20 \%$ & 1 & $10 \%$ & 10 & $100 \%$ \\
\hline $\mathrm{PT}$ & 42 & $43 \%$ & 10 & $10 \%$ & 28 & $28 \%$ & 16 & $17 \%$ & 2 & $2 \%$ & 98 & $100 \%$ \\
\hline PV & 0 & $0 \%$ & 0 & $0 \%$ & 1 & $50 \%$ & 1 & $50 \%$ & 0 & $0 \%$ & 2 & $100 \%$ \\
\hline Total & 61 & $41 \%$ & 16 & $10 \%$ & 44 & $29 \%$ & 27 & $18 \%$ & 3 & $2 \%$ & 151 & $100 \%$ \\
\hline
\end{tabular}

Fonte: Elaboração própria. Obs. Era possível marcar até quatro alternativas.

Esta verificação contrasta com o fato de que a maioria das legendas à esquerda, como o PDT, PPS, PSB e PV, apresentam baixos índices de pronunciamentos favoráveis a ampliação do aborto, inclusive inferiores aos partidos de direita. Entretanto, as posições contrárias ao aborto entre estes são elevadas, por exemplo, de acordo com a Tabela 1: no PSB a soma das três categorias que expressam oposição/repressão ao aborto alcançaram $53 \%$ das falas (33 de 62 posições assinaladas pelo partido), no PDT 38\% (13 de 35), no PV 70\% (39 de 55), no PPS $50 \%$ ( 6 de 12). Para ilustrar esse aspecto apresentamos o excerto do discurso do deputado Marcelo Serafim (PSB-AM), em que são defendidas medidas restritivas ao aborto em caso de estupro e ampliação das penas:

Sr. Presidente, além de ter usado a tribuna por diversas ocasiões para me posicionar contrariamente à legalização do aborto, sou autor do Projeto de Lei nº 2.433/2007, que aumenta a pena de detenção para a gestante que realizar ou consentir o aborto, a pena de reclusão para o aborto realizado por terceiros e que tipifica o crime de induzir, instigar ou auxiliar mulher grávida a abortar. (...).Sr. Presidente, no sentido de corrigir essas distorções propomos que, para o aborto provocado pela própria gestante (art. 124), a pena aumente de 2 a 4 anos. Com a inclusão do art. 124-A, torna-se crime a prática de induzir, instigar e auxiliar a mulher grávida à prática do aborto, sendo a pena para o criminoso de 2 a 6 anos de reclusão.Propomos ainda, senhoras e senhores, que o aborto provocado por terceiros, já previsto no Código atual, tenha a duração da punição aumentada: reclusão de 6 a 20 anos para quem provocar o aborto sem o consentimento da gestante (art. 125); e reclusão de 4 a 15 anos para quem provocar aborto com o consentimento dela (art. 126). (Diários da Câmara dos Deputados, 21/11/07, p. 58417). 
As exceções no campo da esquerda brasileira são o PT, PCdoB e o Partido Socialismo e Liberdade (PSOL), este último mais pela proporção que pela quantidade de falas a favor da ampliação do aborto legal. O Partido dos Trabalhadores (PT) pode ser tomado como o caso mais complexo, não só à esquerda, mas entre todas as instituições do sistema partidário brasileiro. Os/as parlamentares desta legenda foram os que mais se pronunciaram em plenário, sendo responsável por 20,9\% (225 de 1078) do total de discursos da pesquisa. Neste conjunto de discursos proferidos pelos/as parlamentares petistas, a posição a favor da ampliação do aborto legal foi identificada em 86 falas. Este número é elevado, pois representa 58,3\% do total registrado nesta categoria em toda pesquisa. Por outro lado, a posição contra o aborto (genérico) foi assumida em 68 discursos, por novas medidas punitivas e/ ou controle em 17 pronunciamentos e a favor da restrição do aborto legal em 11 discursos.

As posições mais antagônicas assumidas pelos/as deputados/as petistas possuem magnitudes verossímeis. Ao averiguarmos mais detalhadamente os dados, notamos que dos 84 discursos contrários ao aborto, 58 deles foram proferidos pelo deputado Luiz Bassuma (PT-BA), e dos 86 pronunciamentos a favor da ampliação do aborto legal, 33 foram pronunciados pelo parlamentar José Genoíno (PT-SP / de 1985 até 2013) e 21 pela deputada Marta Suplicy (PT-SP / de 1995 até 1999). Isso não significa dizer que estes tenham sido os únicos nomes em defesa da "causa pró-vida" ou pela ampliação do aborto no interior do PT. Isolando os números provenientes dos discursos dos/a parlamentares supracitados, então teríamos um cenário de 32 pronunciamentos a favor da ampliação do aborto legal, proferidos por 18 parlamentares (principalmente: Cida Diogo (RJ), Eduardo Jorge (SP), Sandra Starling (MG) e Janete Rocha Pietá (RJ). Já no espectro oposto seriam 26 discursos com alguma das três posições contrárias, proferidos por 14 parlamentares(principalmente: Hélio Bicudo (SP), Nazareno Fonteles (PI), Angela Guadagnin (SP) e Henrique Afonso (AC).

As posições pela educação sexual e/ou planejamento familiar e a favor da manutenção da lei apresentam uma característica distinta da conotação proferida pelos/as parlamentares dos partidos à direita, centro-direita e ao centro do sistema partidário. Entre os partidos de esquerda, sobretudo PC do B e PT, a posição pela educação sexual e/ou planejamento familiar serviu para apresentar proposições com o intuito de oferecer programas educacionais à população, assim como foi um dos principais fundamentos para coibir as ações de esterilizações de mulheres pobres no Nordeste do País, promovidas por organizações internacionais nas décadas de 1980 e 1990. Por sua vez, a posição a favor da manutenção da lei foi serviu de suporte para os/as parlamentares de esquerda se colocarem contrários às restrições, diante de proposições para criminalizar o aborto em casos já previstos em lei. 


\section{Gráfico 3: \\ Distribuição dos discursos contrários ao aborto (três categorias fundidas) e a favor da ampliação do aborto legal do PSB, PCdoB e PDT, entre 1985-2016}

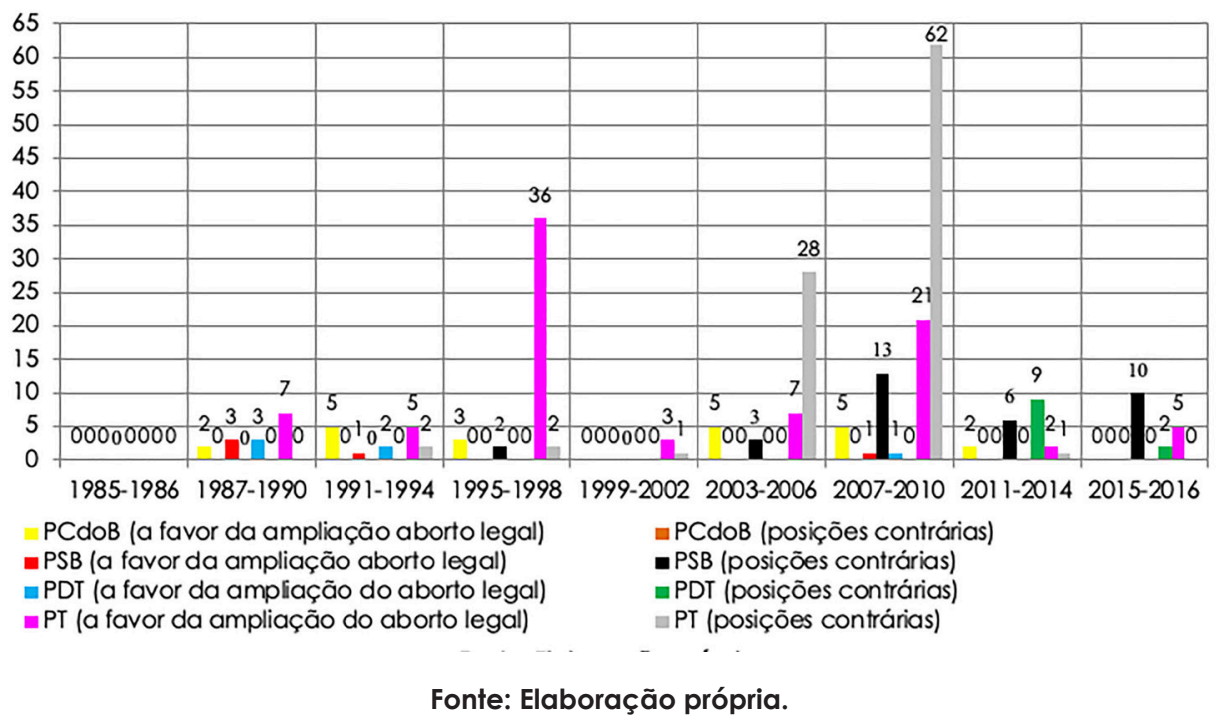

Ográfico acima nos apresenta indicadoresrelevantes sobre os dados, impossíveis de perceber na apresentação geral das tabelas. Em primeiro lugar, é possível notar que de 1985 até 2002 as posições no campo da esquerda estavam majoritariamente concentradas na defesa pela ampliação do direito ao aborto legal, com registros isolados de discursos com alguma posição contrária. A partir de 2002 esse padrão sofreu alteração significativa, com elevação dos pronunciamentos contrários ao aborto, inclusive na maioria das legislaturas subseqüentes a 2002 foram muito superiores em comparação as falas a favor da ampliação do aborto legal.

A partir desse tratamento dos dados, consideramos que os resultados são claros ao apontar uma tendência conservadora nas manifestações dos/as representantes dos partidos políticos no Brasil, especialmente a partir dos anos 2000. A oposição ao aborto é predominante em todos os espectros ideológicos, com exceção de três partidos à esquerda, são eles: PT, PC do B e PSOL. Diante das evidências apresentadas é possível aferir que este é um fenômeno suprapartidário, o qual apresenta relevante correspondência ao simultâneo crescimento na Câmara dos Deputados das frentes parlamentares confessionais e também das Frentes parlamentares de oposição ao aborto.

Esta verificação é consoante a tese de que no início dos anos 2000 houve maior mobilização de atores e grupos religiosos vinculados às igrejas pentecostais, neopentecostais e a Igreja Católica (especialmente, a Renovação Carismática) para inserção na política institucional, especialmente pela incorporação de estratégias político-eleitorais para eleição de representantes. Além do mais, é a partir deste período também que será possível verificar com mais clareza a composição de uma mobilização regular no Poder Legislativo e a construção de um discurso mais unívoco, que possa caracterizar a agenda dos/as deputados/ as remanescentes dos diferentes segmentos do cristianismo. 
A ascensão no número de parlamentares vinculados a grupos de oposição ao aborto e sua dispersão em quase todos os partidos políticos confere a este segmento poder para pressionar o sistema político-partidário, no sentido de conduzir a discussão sob parâmetros morais e religiosos, por conseguinte, freando qualquer avanço sobre os direitos reprodutivos das mulheres. Agora, é necessário ressaltar que concordamos com as conclusões de Luis Felipe Miguel (2012) e Maria das Dores Machado (2013), no que diz respeito a entender que o expressivo poder de pressão exercido por estes arranjos políticos conservadores não explicam integralmente a vigorosa oposição ao aborto na maioria das legendas partidárias no Brasil. Neste sentido parece válido considerar as concessões e recuos de alguns partidos e/ou representantes políticos em relação à agenda, sobretudo aqueles que desempenharam papel fundamental para a redemocratização e ampliação das liberdades individuais, tais como: os partidos à esquerda, de centro-esquerda (como: PDT. PSB, PPS e PV) e até os situados no centro no sistema partidário (PMDB e PSDB). Como vimos os/as deputados/ as de algumas destas legendas apresentam padrão semelhante (até inferior) de posições favoráveis ao aborto em comparação àqueles vinculados aos partidos mais à direita no País, que historicamente sempre se opuseram a qualquer avanço na agenda moral. Por um lado, devemos observar a permeabilidade destes partidos ao incorporar entre seus quadros políticos parlamentares cujas posições sobre o aborto são de caráter regressivo. Por outro lado, avaliar estes recuos como processo estratégico, neste caso, evitar custos políticos ao tratar de um assunto polêmico. Na tabela abaixo é apresentada a composição de todas as Frentes parlamentares sobre o aborto formadas na Câmara dos Deputados do Brasil.

Tabela 8:

Frentes Parlamentares sobre aborto na Câmara dos Deputados.

\begin{tabular}{|c|c|c|c|c|c|}
\hline \multicolumn{2}{|c|}{ Frente Parlamentar } & \multirow{3}{*}{$\begin{array}{c}\begin{array}{c}\text { Defesa da vida } \\
\text { - contra } \\
\text { aborto }\end{array} \\
2005 \\
193 \text { deputados }\end{array}$} & \multirow{4}{*}{$\begin{array}{c}\text { Família e } \\
\text { apoio à vida } \\
\text { Não havia sido } \\
\text { proposta }\end{array}$} & \multirow{4}{*}{$\begin{array}{c}\text { Contra a } \\
\text { legalização } \\
\text { do aborto } \\
\text { Não havia } \\
\text { sido } \\
\text { proposta }\end{array}$} & \multirow{4}{*}{$\begin{array}{c}\text { Defesa da Vida } \\
\text { e da Família }\end{array}$} \\
\hline \multirow{3}{*}{$\begin{array}{c}52^{\circ} \\
\text { Legislatura } \\
2003-2006\end{array}$} & Ano de registro & & & & \\
\hline & Signatários & & & & \\
\hline & Presidida & $\begin{array}{c}\text { Luiz Bassuma } \\
\text { (PT-BA) }\end{array}$ & & & \\
\hline \multirow{3}{*}{$\begin{array}{c}53^{\circ} \\
\text { Legislatura } \\
2007-2010\end{array}$} & Ano de registro & 2007 & 2007 & 2007 & \multirow{3}{*}{$\begin{array}{c}\text { Não havia sido } \\
\text { proposta }\end{array}$} \\
\hline & Signatários & 202 deputados & 197 deputados & $\begin{array}{c}194 \\
\text { deputados }\end{array}$ & \\
\hline & Presidida & $\begin{array}{l}\text { Luiz Bassuma } \\
\text { (PT-BA) }\end{array}$ & $\begin{array}{c}\text { Bispo } \\
\text { Rodovalho } \\
\text { (PFL/DF) }\end{array}$ & $\begin{array}{c}\text { Leandro } \\
\text { Sampaio } \\
\text { (PPS-RJ) }\end{array}$ & \\
\hline \multirow{3}{*}{$\begin{array}{c}54^{\circ} \\
\text { Legislatura } \\
2011-2014\end{array}$} & Ano de registro & 2011 & 2011 & \multirow{3}{*}{$\begin{array}{l}\text { Não foi } \\
\text { relançada }\end{array}$} & \multirow{3}{*}{$\begin{array}{c}\text { Não havia sido } \\
\text { proposta }\end{array}$} \\
\hline & Signatários & 192 deputados & 202 deputados & & \\
\hline & Presidida & $\begin{array}{c}\text { Salvador } \\
\text { Zimbaldi } \\
\text { (PMDB - SP) }\end{array}$ & $\begin{array}{l}\text { Fátima Pelaes } \\
\text { (PMDB-AP) }\end{array}$ & & \\
\hline \multirow{3}{*}{$\begin{array}{c}55^{\circ} \\
\text { Legislatura } \\
2015-2019\end{array}$} & Ano de registro & \multirow{3}{*}{$\begin{array}{l}\text { Não foi } \\
\text { relançada }\end{array}$} & 2015 & \multirow{3}{*}{$\begin{array}{l}\text { Não foi } \\
\text { relançada }\end{array}$} & 2015 \\
\hline & Signatários & & 207 deputados & & 236 deputados \\
\hline & Presidida & & $\begin{array}{l}\text { Ronaldo } \\
\text { Fonseca } \\
\text { (PRONA-DF) }\end{array}$ & & $\begin{array}{c}\text { Pastor Alan } \\
\text { Rick (PRB-AC) }\end{array}$ \\
\hline
\end{tabular}

Fonte: Elaboração própria. 
A tendência constatada no Brasil é confluente, em boa medida, com os resultados verificados por outras investigações realizadas nos países da América Latina, as quais também têm verificado uma relação complexa dos partidos políticos à esquerda com a questão do aborto. A relevância do tema transformou o assunto em agenda de investigação instigante, com diagnósticos originais e específicos sobre a realidade de cada país. Na maioria dos estudos são apresentadas conclusões que, em distintos graus, desconstroem a relação causal (ou vínculo intrínseco) entre os partidos à esquerda e a plena incorporação da demanda pelos direitos reprodutivos das mulheres (Alcântara; Rivas, 2013; Lamas, 2008; Vaggione, 2006; Tabbush et. al. 2016).

A ascensão de governos na América Latina com plataformas progressistas e emancipacionistas fomentou o interesse por este objeto de pesquisa. Por um lado, utilizando as discussões sobre legislações no âmbito do Poder Legislativo, especificamente em países como Chile, Argentina, Brasil e Bolívia, em que houve divisões nos partidos à esquerda. Por outro lado, as posições sobre o assunto na esfera do Poder Executivo, as quais culminaram na obstrução da discussão sobre o aborto, bem como em medidas implementadas de aspecto conservador, tais como: 1) o veto do Presidente Tabaré Vásquez, da Frente Ampla, ao projeto de lei para descriminalização do aborto no Uruguai em 2008; 2) Na Nicarágua, a proibição do aborto em qualquer circunstância em 2007, durante o governo de Daniel Ortega, da Frente Sandinista de Libertação Nacional ${ }^{6}$, revogando a legislação que permitia sua realização para salvar a vida da gestante, em casos de estupro e má-formação do feto; 3) e no Equador, a militância do Presidente Rafael Correa, do Alianza País, alinhado ao movimento "Pró-Vida", para impedir a deliberação de projetos de lei sobre o aborto, elaborados por parlamentares de seu partido político (Alcántara; Rivas, 2013; Lamas, 2008). Algumas variáveis têm apresentado potencial capacidade de explicação para este quadro. Em primeiro lugar é preciso avaliar que boa parte dos partidos políticos à esquerda na região foram formados a partir da Igreja Católica, especificamente de setores da Teologia da Libertação durante regimes autoritários nas décadas de sessenta e setenta. Por mais que a Teologia da Libertação tenha se caracterizado pela mobilização para a democratização das instituições e a denúncia das desigualdades sociais no continente, sempre houve enorme resistência as questões de gênero, como o aborto e o divórcio, as quais jamais foram incorporadas como temas vinculados à justiça social e direito das mulheres (Lamas, 2008; Machado, 1996). No cenário recente, a relação dos partidos políticos à esquerda em cada país com setores do catolicismo se conforma de diferentes maneiras, por vezes em maior e outras em menor grau, o que de algum modo contribui para entender os níveis de intervenção da hierarquia da Igreja Católica sobre os/as parlamentares nas deliberações em plenário, bem como nas ações de governo no tocante aos direitos reprodutivos e sexuais das mulheres. Em segundo lugar, as esquerdas da América Latina se construíram essencialmente a partir de questões classistas, portanto, demandas identitárias e de gênero ocuparam espaço periférico no escopo de suas ações (Vaggione, 2006; Tabbush et. al. 2016).

6 Manuel Alcántara e Cristina Rivas (2013) destacam que esta inclinação representou mudança radical na posição do partido sandinista sobre o aborto, motivada pelo apoio da Igreja Católica no período pré-eleitoral. 
De todo modo, Juan Marco Vaggione (2006) avalia que mesmo diante de resistências internas, os governos de centro à esquerda no continente, especialmente no Uruguai, Argentina, Chile e Brasil representaram uma abertura de oportunidade para aprofundar a discussão e inseri-la no debate público, assim como modificar a legislação dos direitos reprodutivos, seja para descriminalizar o aborto ou incluir casos em que a lei não se aplica. Marta Lamas (2008) e ConstanzaTabbush et. al. (2016) sustentam que esse processo é reflexo da tensão provocada pelos movimentos feministas, deflagrando cenários de conflito no interior dos partidos políticos e com os governos à esquerda, para enquadrar o aborto como questão de saúde pública e para garantir as liberdades democráticas.

\section{Partidos políticos e o aborto no Uruguai}

O Uruguai se declarou Independente em 1830, após o fim da Guerra da Cisplatina. Entre os anos de 1939 a 1952 aconteceu a chamada Grande Guerra, que ocorreu entre os grupos rivais do país, denominados "Blancos" e "Colorados", com vitória deste último. O Partido Nacional (blanco) e o Partido Colorado são remanescentes destes grupos políticos. Sendo assim, o sistema partidário uruguaio possui mais de 150 anos de história. Caracterizado por sua estabilidade institucional, este sistema foi composto na maior parte de seu tempo de existência por estes dois partidos hegemônicos.

O Partido Colorado é uma força política composta por grupos de inclinação liberal, progressista e socialdemocrata. Esta agremiação partidária ocupou majoritariamente o Poder Executivo na história política do país, seu potencial eleitoral é derivado, em boa medida, por sua ampla adesão entre a população urbana, principalmente na capital Montevidéu, cidade na qual reside mais de 50\% da população uruguaia. O Partido Colorado se notabilizou pela realização de reformas estruturais, entre os séculos XIX e XX, para construir a laicidade do Estado como princípio regente da esfera pública (ver: Silva, 2018b). Além do mais, pela implementação pioneira de direitos sociais, políticos e individuais no início do século XX, tais como: o direito ao voto às mulheres, lei do divórcio pela vontade da mulher e eutanásia.

O Partido Nacional (Blancos) é uma agremiação política integrada por muitos setores de inspiração ideológica de direita e centro-direita, desse modo, seus representantes apresentam posições mais conservadoras no campo político e social, na economia por posturas desestatizantes e em prol do livre mercado. Os Blancoshistoricamente possuem significativa influência eleitoral entre a população rural, assim seu peso político se concentra no Poder Legislativo e também em unidades subnacionais de governo. Esta instituição partidária se caracteriza, entre outros aspectos, pela oposição a políticas com potencial de alteração nos paradigmas de comportamentos na sociedade e nos valores morais. 
O surgimento da Frente Ampla em 1971 (em meio a ruptura institucional nos anos setenta) viria a transformar o bipartidarismo uruguaio em multipartidarismo/pluralismo moderado. Este reconfiguração do sistema partidário ocorreu mediante o crescimento eleitoral da Frente Ampla após a redemocratização em 1985 (Garcé e Yaffé 2005). Por exemplo, Tabaré Vázquez (FA) assumiu como Prefeito de Montevidéu em 1990. Desde então, expandiu consideravelmente sua bancada nas duas casas legislativas até se consolidar no Poder Executivo nacional a partir de 2005 até 2020, ao eleger três Presidentes de forma consecutiva.

O impacto que a Frente Ampla promoveu no sistema partidário não se resume somente a conquista de cargos eletivos, mas também pela redefinição dos papéis das forças que compõem este sistema. Visto que, os partidos tradicionais desde a redemocratização até 2005 se revezaram no Poder Executivo e se empenharam neste período em implementar reformas neoliberais, no geral, impopulares aos uruguaios. Assim, a Frente Ampla logrou êxito ao se apresentar como alternativa eleitoral a estes partidos e suas propostas, justamente por defender os valores que eram os alicerces da cultura política dos uruguaios, tais como, a defesa de posições estatistas, distributivas e em prol da igualdade (Lanzaro 2003). Com isso, se situou em um espectro ideológico outrora ocupado pelo Partido Colorado. Para enfrentar a quase hegemonia do poder político da Frente Ampla, nos últimos anos ocorreu o alinhamento político (e ideológico) entre Blancos e Colorados, rivais históricos.

Este esboço sobre a formação e modificações no sistema partidário uruguaio auxilia na compreensão do posicionamento dos partidos políticos sobre o aborto. Abaixo apresentamos as tabelas com os resultados identificados pela pesquisa, quanto a posição dos/as parlamentares sobre o aborto, de acordo com a filiação partidária.

Tabela 9:

Distribuição dos discursos de acordo a posição dos partidos políticos sobre o aborto no Uruguai, em números absolutos e percentuais (em coluna), entre 1985-2016.

\begin{tabular}{|c|c|c|c|c|c|c|c|c|}
\hline Partido $\rightarrow$ & \multicolumn{2}{|c|}{$\begin{array}{c}\text { Frente } \\
\text { Amplia }\end{array}$} & \multicolumn{2}{c|}{$\begin{array}{c}\text { Partido } \\
\text { Colorado }\end{array}$} & \multicolumn{2}{c|}{$\begin{array}{c}\text { Partido } \\
\text { Nacional }\end{array}$} & \multicolumn{2}{c|}{ Total } \\
\cline { 2 - 10 } & $\mathbf{Q}$ & $\%$ & $\mathbf{Q}$ & $\%$ & $\mathbf{Q}$ & $\%$ & $\mathbf{Q}$ & $\%$ \\
\hline $\begin{array}{c}\text { A favor da ampliação do aborto } \\
\text { legal }\end{array}$ & 130 & $76 \%$ & 24 & $32 \%$ & 0 & $0 \%$ & 154 & $42,7 \%$ \\
\hline A favor da manutenção da lei & 13 & $8 \%$ & 22 & $30 \%$ & 29 & $25 \%$ & 64 & $17.7 \%$ \\
\hline $\begin{array}{c}\text { A favor da restrição do aborto } \\
\text { legal }\end{array}$ & 1 & $0,6 \%$ & 0 & $0 \%$ & 1 & $1 \%$ & 2 & $0,6 \%$ \\
\hline $\begin{array}{c}\text { Contra o aborto (genérico) } \\
\text { Por novas medidas punitivas e/ou } \\
\text { de controle }\end{array}$ & 10 & $5.4 \%$ & 14 & $18 \%$ & 66 & $58 \%$ & 90 & $24,8 \%$ \\
\hline $\begin{array}{c}\text { Pela educação sexual e/ou } \\
\text { planejamento familiar }\end{array}$ & 18 & $10 \%$ & 15 & $20 \%$ & 17 & $15 \%$ & 50 & $14 \%$ \\
\hline TOTAL & 172 & $100 \%$ & 75 & $100 \%$ & 114 & $100 \%$ & 361 & $100 \%$ \\
\hline
\end{tabular}

Fonte: Elaboração própria. Obs.: Era possível marcar até duas alternativas. Partidos políticos menores e com menos de 10 pronunciamentos na série histórica foram excluídos.

7 É a coalizão de diversos grupos políticos com distintas inspirações, tais como, socialistas, progressistas, revolucionárias, do cristianismo social, entre outras. 
Tabela 10:

Distribuição dos discursos de acordo com o tipo de ampliação de acesso ao aborto e a filiação partidária no Uruguai, em números absolutos e percentuais (em linha), entre 1985 e 2016

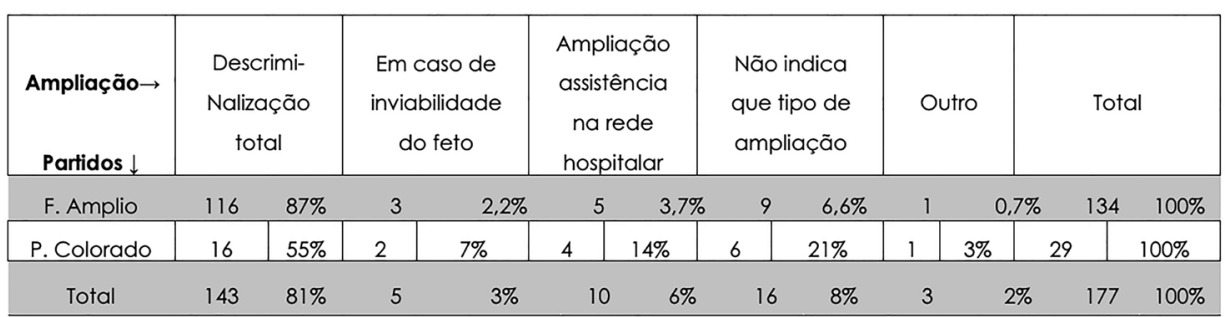

Fonte: Elaboração própria. Obs. Era possível marcar até quatro alternativas em cada discurso. Por não haver nenhum discurso o Partido Nacional foi exclú́do.

Tabela 11:

Distribuição dos discursos de acordo com o tipo de restrição ao aborto e a filiação partidária do/a parlamentar no Uruguai, em números absolutos e percentuais (em linha), entre 1985 e 2016.

\begin{tabular}{|c|c|c|c|c|c|c|c|c|c|c|c|c|}
\hline \multirow{2}{*}{$\begin{array}{l}\text { Restrição } \rightarrow \\
\text { Partido } \downarrow \\
\text { F. Amplio } \\
\end{array}$} & \multicolumn{2}{|c|}{ Proibição total } & \multicolumn{2}{|c|}{ Estupro } & \multicolumn{2}{|c|}{$\begin{array}{c}\text { Risco de vida da } \\
\text { mãe }\end{array}$} & \multicolumn{2}{|c|}{$\begin{array}{c}\text { Inviabili-dade } \\
\text { do feto }\end{array}$} & \multicolumn{2}{|c|}{$\begin{array}{c}\text { Políticas de } \\
\text { repressão ao } \\
\text { aborto }\end{array}$} & \multicolumn{2}{|c|}{ Total } \\
\hline & 0 & $0 \%$ & 0 & $0 \%$ & 0 & $0 \%$ & 1 & $100 \%$ & 0 & $0 \%$ & 1 & $100 \%$ \\
\hline P. Nacional & 1 & $50 \%$ & 0 & $0 \%$ & 0 & $0 \%$ & 0 & $0 \%$ & 1 & $50 \%$ & 2 & $100 \%$ \\
\hline Total & 1 & $33,3 \%$ & 0 & $0 \%$ & 0 & $0 \%$ & 1 & $33,3 \%$ & 1 & $33,3 \%$ & 3 & $100 \%$ \\
\hline
\end{tabular}

Fonte: Elaboração própria. Obs. Era possível marcar até cinco alternativas em cada discurso. Por não haver nenhum discurso o Partido Colorado foi excluído.

Ao analisar a tabela 9 percebemos que o Partido Colorado representa a força política mais centro em relação às posições sobre o aborto. Na série histórica foram analisados 68 pronunciamentos de parlamentares deste partido. Nenhum destes se pronunciou em favor da restrição do aborto legal e/ou por novas medidas punitivas e/ou controle. As demais categorias possuem magnitudes equilibradas, ainda que a posição a favor da ampliação do aborto legal seja superior.

Este quadro geral apresenta distorções quanto às posições dos/as deputados/as Colorados, as quais merecem ser esmiuçadas para diagnosticar duas situações. A primeira se refere ao período entre 1985-1998, em que os/as parlamentares deste partido estiveram entre os/as protagonistas pela descriminalização do aborto. Dos nove pronunciamentos deste partido enunciados no período, oito se posicionam a favor da ampliação do aborto legal (ver: Gráfico 4). Somado a isso, os dois projetos de lei apresentados em 1985 (PL 385/85) e 1993 (PL 3107/93), com o objetivo de descriminalizar o aborto foram de (co) autoria dos/as deputados/as Colorados. 
A segunda situação identificada ocorreu a partir de 2004, quando posições contrárias começaram a ser sustentadas. Além disso, após 1993, nenhum dos projetos pró-descriminalização apresentados na Câmara de Representantes contou com a (co) autoria de algum parlamentar Colorado, pelo contrário, em 2011 o deputado Fernando Amado apresentou o projeto de lei $851 / 11$, para criminalizar o aborto.

Neste sentido, o Partido Colorado se deslocou de uma posição majoritariamente a favor da ampliação do aborto legal, nas manifestações em plenário e também nas legislações propostas, para a localização centro/contrária no debate sobre a matéria. De acordo com que foi exposto acima, acreditamos que este reposicionamento do Partido Colorado quanto ao tema possui relação com as transformações no interior do partido político, assim como no sistema partidário, ou seja, o advento da Frente Ampla e seu alinhamento ao Partido Nacional. No gráfico abaixo apresentamos a distribuição dos pronunciamentos sobre o aborto, de acordo com a posição, durante o período de análise.

\section{Gráfico 4:}

Distribuição dos discursos contrários ao aborto (três categorias fundidas) e a favor da ampliação do aborto legal da Frente Amplia (FA), Partido Nacional (PN) e Partido Colorado (PC), entre 1985-2016.

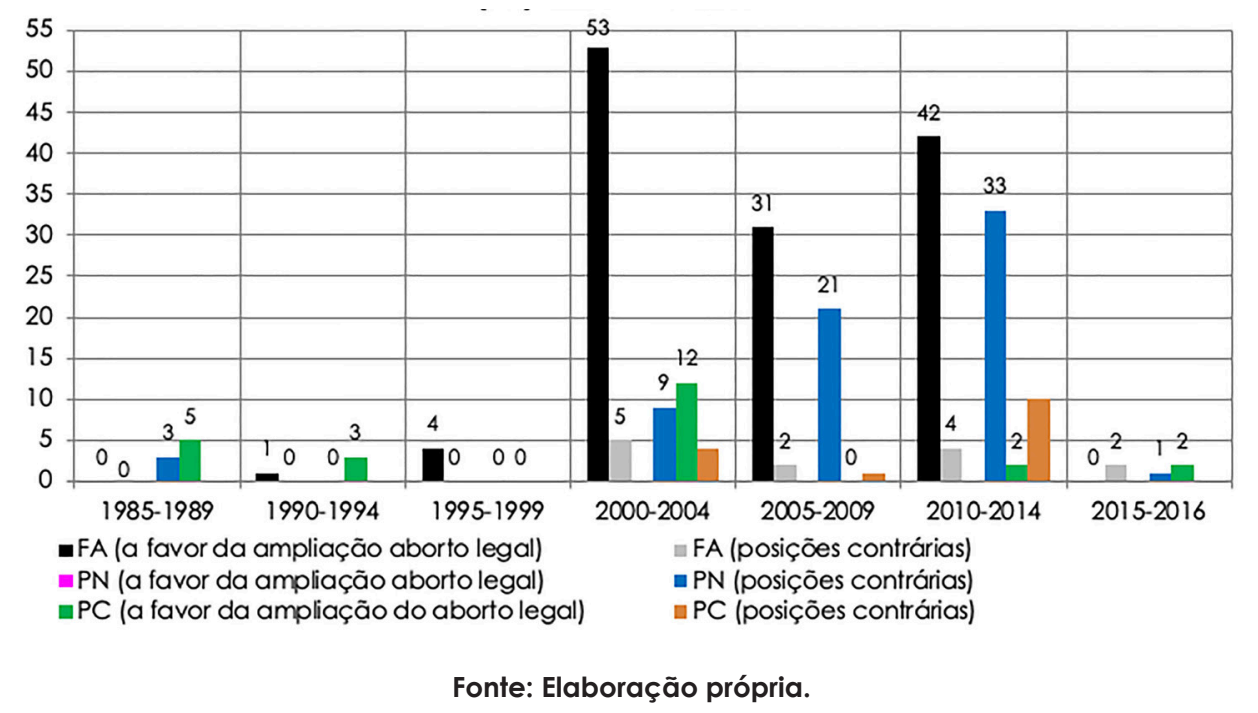

Como é possível verificar nas tabelas e no gráfico, o Partido Nacional apresenta as posições mais conservadoras em relação ao aborto. A ampla maioria das posições contra o aborto (genérico) está entre os pronunciamentos deste partido. Entre os 91 discursos examinados dos/as deputados/as Blancos nenhum deles foi proferido com a posição a favor da ampliação ao aborto legal. Não obstante, convém ressaltar também que, durante os anos oitenta e noventa não houve registros por parte deste partido (nem de outros) de iniciativas ou pronunciamentos na promoção de medidas para a ampliação da criminalização do aborto, o que é uma constatação relevante, considerando que a legislação do país era constituída por número amplo de permissões até 2012, tais como a realização do aborto 
em casos de penúria econômica e/ou quando representava risco à saúde da gestante. Do mesmo modo, salientar o número expressivo de pronunciamentos a favor da manutenção da lei, que de fato expressaram objeção à aprovação da descriminalização do aborto no processo deliberativo, mas esta oposição se construiu em bases moderadas, ou seja, sem retrocessos nas exceções previstas até 2012. Essa observação demonstra certa diversidade no interior do Partido Nacional quanto ao assunto.

Esse padrão de oposição ao aborto parece sofrer alterações, já que desde 2008 alguns deputados do Partido Nacional foram autores de três projetos de lei (de todos os quatro apresentados) com a finalidade de restringir o aborto (são eles: PL 2755/2008; PL 559/2010; PL 56/2015; ver: Silva, 2018). Assim, podemos verificar uma mobilização ainda em curso, mas organizada para imprimir recuos na legislação aprovada em 2012, conduzida principalmente por esta instituição partidária.

Essa mobilização pode ser verificada também pela elevação gradativa das manifestações contrárias entre 2002 e 2012 (ver: Gráfico 4), que ocorrem em virtude do crescimento político-eleitoral dos Blancos. Neste sentido, é razoável refletir que a ascensão eleitoral e a preservação do engajamento em torno da matéria entre os Blancos, podem incidir em alterações na legislação para restringir o aborto em cenários futuros.

A Frente Ampla é o principal partido do sistema uruguaio a defender a descriminalização do aborto. Seus deputados/as se pronunciaram sobre o tema em 158 discursos, destes $98,3 \%$ (155) efetuados somente a partir de 1998. Não significa dizer que até este ano sua atuação era discreta em relação ao aborto, pelo contrário, no projeto de lei de 1993 a maioria dos/ as co-autores/as eram da Frente Ampla. Esta informação apenas constata, conforme dito antes, que seu peso político até então era periférico e sua inserção no cenário político aconteceu de modo gradual após a redemocratização, em comparação ao Partido Colorado e Nacional. Ademais, isto também associa, de certo modo, a inscrição recorrente dos direitos reprodutivos na agenda de discussão parlamentar a partir dos anos 2000, com o crescimento da Frente Ampla no legislativo no mesmo período. As razões para considerar esta associação repousam no protagonismo dos/as deputados/as do partido, tanto na deliberação em plenário como na elaboração de projetos de lei em prol da matéria. Este partido registrou os maiores índices de posições a favor da ampliação do aborto legal, que são superiores aos de todos os outros somados após os anos 2000. Das 130 posições favoráveis (76\% das falas do partido), 87\% (1 16) assinalaram como ampliação a descriminalização total. O pronunciamento da deputada Bertha Sanseverino (FA-Montevidéu), acerca da mortalidade materna, é um exemplo dessa construção:

(...) Con respecto a Uruguay, la tasa de mortalidad materna es la más baja de la región, pero la mayoría de los casos son evitables. La mitad de ellos se originan en casos de abortos provocados en condiciones de riesgo. Por ello, en 2002 se puso en marcha el Programa Iniciativas Sanitarias, contra el aborto provocado en condiciones de riesgo. La Ley $N^{\circ} 18.426$, relativa a la defensa de la salud sexual y reproductiva, aprobada en 2008, establece que el Estado garantizará las condiciones para el ejercicio pleno de los derechos sexuales y reproductivos de toda la población. Uruguay avanza en 
la universalización de dichos servicios y también en el acceso a los métodos anticonceptivos, estableciendo la obligación para todas las instituciones médicas de prestar este servicio. Esta ley introduce el asesoramiento preaborto, por el que todas las mujeres tienen derecho al asesoramiento integral, previsto en el parágrafo 8.25 del programa de acción de la Conferencia de El Cairo. (Uruguay, Diario de Sesiones, 18/09/2012, p. 33).

A despeito disso os números de discursos contrários da Frente Ampla devem ser avaliados como expressivos, por exemplo, são similares aos do Partido Colorado, além disso, foi registrado um pronunciamento a favor da restrição ao aborto. Acreditamos que para entender estes números é preciso levar em consideração a heterogeneidade do partido, composto por múltiplas tendências, entre elas, frações do catolicismo social. Isto dito, pois mais da metade dos deputados que se posicionaram desta forma apontaram razões religiosas e se auto-declararam cristãos nos discursos (são eles: Jorge Fonticiella; José Luís Veja; Eduardo LayÁlvez; Juan Andrés Roballo). Nesta agenda política, a relação entre setores da Frente Ampla com segmentos mais conservadores da sociedade é avaliada como um dos elementos explicativos para o veto do Presidente Tabaré Vázquez a descriminalização do aborto em 2008, especialmente por seu vínculo e interlocução naquela ocasião com Monsenhor Cotugño(Rostagnol, 2009; Johnson, Rocha, Schenck, 2015).

Sendo assim, os dados convergem à verificação de que a Frente Ampla é o principal partido no sistema político uruguaio a inserir o assunto como matéria de deliberação no Poder Legislativo, assim como na atuação à aprovação da descriminalização do aborto. Porém os resultados também constatam a heterogeneidade desta agremiação, pois apesar de periféricas as manifestações em oposição aos direitos reprodutivos das mulheres demonstram pontos de tensão no entendimento desta agenda no interior do partido.

\section{Considerações finais}

Este texto apresenta os resultados gerais da investigação, com foco específico sobre a relação entre os partidos políticos de Brasil e Uruguai à agenda da interrupção voluntária da gravidez. Os resultados mais relevantes identificados nos discursos indicam que no Brasil a defesa dos direitos reprodutivos é uma agenda com baixa adesão nos pronunciamentos dos/as Deputados Federais, com elevados registros de posições com conotações mais regressivas e punitivas. A vigorosa oposição ao aborto é um fenômeno suprapartidário, sendo verificada em todos os espectros ideológicos. Desde já, estas constatações instigam a avaliar o cenário brasileiro com cautela, requerendo outros esforços analíticos (a partir e com base nessa exposição geral dos dados), para examinar com maior profundidade as variáveis salientadas como explicativas, tais como: a significativa afluência de representantes vinculados a grupos cristãos no Poder Legislativo, os recuos estratégicos na agenda sobre o aborto e até refletir sobre a composição dos partidos à esquerda ou de conotação progressista.

No Uruguai há um cenário de maior definição, já que a questão do aborto apresenta-se como uma agenda presente exclusivamente entre partidos políticos do centro à esquerda, Partido Colorado e Frente Ampla, em que boa parte de seus/suas representantes enquadram o aborto como direito humano e direito às liberdades laicas, ênfase e compreensão 
minoritária nos partidos brasileiros neste espectro ideológico. Apesar disso são relevantes os registros de que mesmo nestas agremiações a questão do aborto enfrenta resistências e mobilizações significativas, como o veto do Presidente Tabaré Vásquez à descriminalização em 2008, bem como a atuação preponderantemente conservadora no quadro recente de alguns parlamentares Colorados. Por sua vez, entre os/as parlamentares do Partido Nacional é hegemônica a oposição à descriminalização do aborto, entretanto cabe ressaltar diferenças com relação aos partidos à direita no Brasil. Por um lado, não há registros explícitos de que seus/suas representantes sejam interlocutores de grupos religiosos de matriz cristã, por outro, a posição dos Blancos não se configura em demandas por regressões na legislação, como restrição em caso de estupro. De todo modo é razoável estimar que mudanças no cenário político-eleitoral podem ter reflexo nesta agenda, especialmente a partir da eleição de Luis Alberto LacallePou (Partido Nacional) à Presidência do Uruguai em 2019, o qual foi (co) autorde três dos quatro projetos para imprimir recuos na legislação aprovada em 2012.

\section{Bibliografia}

Alcântara, M. y Rivas, C. (2013).Opinión sobre el aborto desde la perspectiva de los legisladores latinoamericanos. Elites Parlamentarias Latinoamericanas. (54), 1-5. Recuperado de: https://demo.europeana.eu/pt/item/2022712/lod_ oai_gredos_usal_es_10366_122580_ent0

Codato, A, Berlatto, F; Bolognesi, B. (2018). Tipologia dos políticos de direita no Brasil: uma classificação empírica. Análise Social, (229), 870-897. DOI: https:// dx.doi.org/10.31447/as00032573.2018229.02

Garcé, A. yYaffé, J. (2005).La Era Progresista. Montevideo, Uruguai:Editora Fin de Siglo.

Johnson, N. Rocha, C. y Schenck, M. (2015). La inserción del Aborto en la Agenda político-pública uruguaya 1985-2013: Un análisis desde el Movimiento Feminista. Montevidéu, Uruguai:Editora. UdelaR. Acesso livre disponível em: https:// cotidianomujer.org.uy/sitio/pdf/abortol5web.pdf

Kinzo, M. D.(2001). A democratização brasileira: Um balanço do processo político desde a transição. São Paulo em Perspectiva, (15), n. 4, 3-12. DOl: http://dx. doi.org/10.1590/S0102-88392001000400002

Lamas, M. (2008). El aborto en la agenda del desarrollo en América Latina. Perfiles Latinoamericanos, (31), 65-93. Recuperado de: https://perfilesla.flacso.edu. $\mathrm{mx} /$ index.php/perfilesla/article/view/186

Lamounier, B. yMeneguello, R. (1987).Partidos políticos e consolidação democrática: O caso brasileiro. São Paulo, Brasil: Editora Brasiliense.

Lanzaro, J. (2003). Os Partidos Uruguaios: a transição na transição. Revista Opinião Pública, (IX), $n^{\circ}$ 2, 46-72.doi: http://dx.doi.org/10.1590/s010462762003000200003

Machado, M. D. (1996).Carismáticos e pentecostais: a adesão religiosa na esfera familiar. São Paulo, Brasil: Editora Autores associados/ANPOCS.

(2013). Discursos pentecostais em torno do aborto e da homossexualidade na sociedade brasileira. RevistaCultura y Religión, (VII) 2, 48-68. Recuperado de:

https://www.revistaculturayreligion.cl/index.php/culturayreligion/article/ view/387/329

Miguel, Luis Felipe (2012). Aborto e democracia. Revista Estudos Feministas, (20), n.3, 657-672.doi: https://doi.org/10.1590/S0104-026X2012000300004

Motta, R. (2008). A reforma partidária de 1979-1980 e o quadro atual. In: R. Motta, Introdução à história dos partidos políticos brasileiros (pp. 104-115). Belo Horizonte, Brasil: Editora UFMG.

Rodrigues, L. (2002). Partidos, ideologia e composição social. Revista Brasileira de Ciências Sociais, 17(48), 31-47. DOl: https://doi.org/10.1590/s0102- 
69092002000100004

Rostagnol, S. (2009). Panorama do aborto no Uruguai. In: M. Rocha; R. Barbosa (organizadoras), Aborto no Brasil e países do Cone Sul (pp. 91-109). Campinas, Brasil: Editora Unicamp. Acesso livre disponível em: http://www.nepo.unicamp.br/textos/publicacoes/livros/aborto/aborto.pdf

Silva, L. G. (2018). Sobre corpos, crucifixos e liberdades: a laicidade do Estado analisada a partir do debate legislativo sobre o aborto no Brasil e no Uruguai (1985-2016). 2018. 283 f., il. Tese (Doutorado em Ciência Política)-Universidade de Brasília, Brasília. Recuperado de: https://repositorio.unb.br/handle/10482/32761

- (2018b). Laicidade do Estado no Uruguai: Considerações a partir do debate parlamentar sobre o aborto (1985-2016). Religião \& Sociedade, 38(2), 5384. https://doi.org/10.1590/0100-85872018v38n2cap02

- (2017). Desenho da pesquisa: o debate legislativo sobre o aborto no Brasil e no Uruguai. Revista Teoria \& Pesquisa, UFSCar, v. 26, n³ 3, 235-251. DOI: https:// doi.org/10.4322/tp.v26i3.616

Tabbush, C. et. al. (2016). Matrimonio igualitario, identidad de género y disputas por el derecho al aborto en Argentina. La política sexual durante el kirchnerismo (20032015). Sexualidad, Salud y Sociedad-Revista Latinoamericana, (22), 22-55.DOI:https://doi.org/10.1590/1984-6487.sess.2016.22.02.a

Vaggione, J. M. (2006). El aborto: las nuevas fronteras. Red Latinoamericana de Católicas por el Derecho a Decidir. Recuperado de:http://clacaidigital.info/bitstream/handle/123456789/831/Aborto-nuevas\%20fronteras.pdf? sequence=5\&isAllowed=y

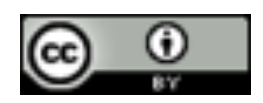

Este es un artículo de acceso abierto bajo licencia Creative Commons Reconocimiento 4.0 Internacional 